\title{
GROWTH RESPONSE ON-FARM OF TWO JATROPHA CURCAS (L.) VARIETIES AS AFFECTED BY MYCORRHIZAE AND ORGANIC MANURE IN THE LOCALITY OF DANG-NGAOUNDERE (ADAMAWA-CAMEROON)
}

\author{
*KABE HINLIBE Karka ${ }^{1,2}$, MEGUENI Clautilde ${ }^{2}$, TCHOBSALA ${ }^{3}$, Augustin SCHINZOUMKA \\ PASSANNET $^{4}$, TCHUENTEU Lucien ${ }^{2}$ and NJINTANG YANOU Nicolas ${ }^{2}$ \\ ${ }^{1}$ Higher National Institute of Agronomic Sciences and Food Technologies of Laï, Department of Agronomic \\ Sciences, BP: 2030, N'Djamena, Chad. \\ ${ }^{2}$ University of Ngaoundere, Faculty of Sciences, Department of Biological Sciences, BP:454, Cameroun \\ ${ }^{3}$ University of Maroua, Faculty of Sciences, Department of Biological Sciences, B P:814, Cameroun \\ ${ }^{4}$ University of Pala, Technical Faculty of Sciences and Technology, Department of the Life Sciences and of Ground, \\ LP 28 Pala, Chad
}

https://doi.org/10.35410/IJAEB.2020.5573

\begin{abstract}
In view of contributing to the establishment and diversification of Jatropha curcas cultivation in the Guinea -savannah of the Adamawa region of Cameroon, a study was carried out to see the effect of organic manure, mycorrhizae and chemical fertilizer on the growth performance of Jatropha curcas in the locality of Dang (Ngaoundere). The experimental design was a split plot with two factors, the first being the origin or accession at two levels (Chad and Cameroon), the second being 4 treatments (organic manure, mycorrhizae, positive control=chemical fertilizer (NPK-20 10 10) and negative control) in three replicates. Data was collected on growth parameters as influenced by the different treatments, total biomass yields, carbon sequestration and root mycorrhizal colonization. Results indicate that fertilizers used have a highly significant effect $(\mathrm{P}<0.001)$ on the growth, development and dry biomass produced at 180 days after sowing, as well as on the level of carbon sequestration. Accessions of local origin (Cameroon) adapted well in the Ngaoundere environment. Organic manure was the most effective in the improvement of growth and development of plants, followed by chemical fertilizers and mycorrhizae. Chemical fertilizer had a negative effect on root mycorrhizal colonization. Organic fertilizers followed by mycorrhizae are seemingly advantageous for the promotion of Jatropha curcas cultivation in the Ngaoundere locality.
\end{abstract}

Keywords: Jatropha curcas, mycorrhizae, organic fertilizer, growth, development, DangNgaoundere..

\section{INTRODUCTION}

Sustainable development policies, the fight against climate change, the high cost of hydrocarbons and the populations' dependence on fossil fuels have motivated research interest on renewable energy resources which are non-polluting and accessible to all (Antonios, 2002). The use of petroleum products by industries produces more carbon dioxide, which is harmful to the environment and health (Péan et al., 2005). Industries are in search of new sources to substitute 
Vol. 5, No. 06; 2020

ISSN: $2456-8643$

fossil fuel whose world reserve can run out by the year 2050 (Chisti, 2007).

The use of plant species in the production of biogas is envisaged. This can contribute in lowering high cost of fuel prices, the world's dependence on fossil fuels and especially contribute to the reduction of green-house gas emission (Fall, 2007). Bio-fuels are renewable energy sources with no negative impact on the environment (Sall, 2007).

In order to ensure food security, research in the domain of bio-energy should be oriented towards non-edible, oil-producing plant species with potentials for bio-fuel production (Dieye, 2007; Jacquet et al., 2009). It is therefore important to produce bio-fuels without compromising agricultural crops destined for human consumption (Bellefontaine et al., 2001; Nwaga, 2009).

Jatropha curcas (pourghère), a shrub belonging to the family Euphorbiaceae, seems a likely alternative to solve the problem of bio-energy without competing with food crops. This plant can be grown in association with other food crops (Dauriat et al., 2001). The toxic end-products (oil and cake) are neither used by humans or livestock, but are appreciated in traditional pharmacopeia (Bellefontaine et al., 2001; Olivier, 2007). The plant adapts to tropical and subtropical climate and the semi-arid regions with annual rainfall of 500 or $700 \mathrm{~mm}$. It withstands long periods of drought ( 3 years), all soil types and requires very little maintenance. It is used for life-fencing and along livestock corridors (Bellefontaine et al., 2001 Olivier, 2007 Tchobsala $e t$ $a l$, 2008). The plant has a plethora of other virtues: oil extracted from the seeds can serve as biofuels or for traditional soap making, rubbing oil, as well as insecticide or nematocide in crop protection (Hammaoui, 2006). The cake obtained after oil extraction is excellent organic manure for crops and when detoxified, can be used as feed for livestock (Kasuya et al., 2013).

The practice of sustainable fertilization with mycorrhizae inoculation and the use of organic manure constitute an alternative for chemical fertilizers which carry serious risks of environmental pollution (Lachance et Rouleau, 2004; Bunch, 2004; Megueni et al., 2011). Organic manures (compost, fowl droppings) and bio-fertilizers (mycorrhizae and rhizobia) permit not only the cleansing of the environment but also increases soil nutrients which are important for the growth of plants (Nwaga, 2000a; 2009b; Tremier et al., 2002).

The general objective of this work is to contribute to the establishment of $J$. curcas in the guinea-savannah region of Ngaoundere (Cameroon). Specifically, this work will consist of:

1) evaluating the impact of mycorrhizae on the growth and development of J. curcas on-farm at Dang;

2) compare the impact of organic manure and mineral fertilizers on the development of the plant;

3) compare the adaptation rate of two accessions of $J$. curcas in the environment of the Adamawa-Cameroon.

\section{MATERIAL AND METHODS}

The trial was carried out on-farm, around the University campus at Dang-Ngaoundere, situated at an altitude of $1084 \mathrm{~m}$, latitude $7^{\circ} 41^{\prime} 132^{\prime}$ ' $\mathrm{N}$ and longitude $13^{\circ} 52^{\prime} 374^{\prime}$ ' $\mathrm{E}$. This is a locality in the Adamawa region (Cameroon), characterized by a guinea-savannah climate with two seasons: a rainy season (mid-March to mid-September) and a dry season (mid-September to mid-March). Rainfall varies between 1200 and $2000 \mathrm{~mm}$, with an average of $1479 \mathrm{~mm}$ with a coefficient of variation of $9.8 \%$. The minimum temperature $\left(10^{\circ} \mathrm{C}\right)$ is registered in the months of December to January and the maximum $\left(34^{\circ} \mathrm{C}\right)$ in the months of March-April. The mean annual temperature 
varies between $22^{\circ} \mathrm{C}$ and $24^{\circ} \mathrm{C}$ and the relative humidity is highest (80\%) in the months of July to August. The soils are basaltic and granites, favorable for agriculture and animal husbandry.

The planting materials are ripe seeds of Jatropha curcas harvested in the locality of Moundou (South of Chad) and from Garoua (North Cameroon). There is no noticeable morphological difference between the seeds from the different origins (Figure 1).

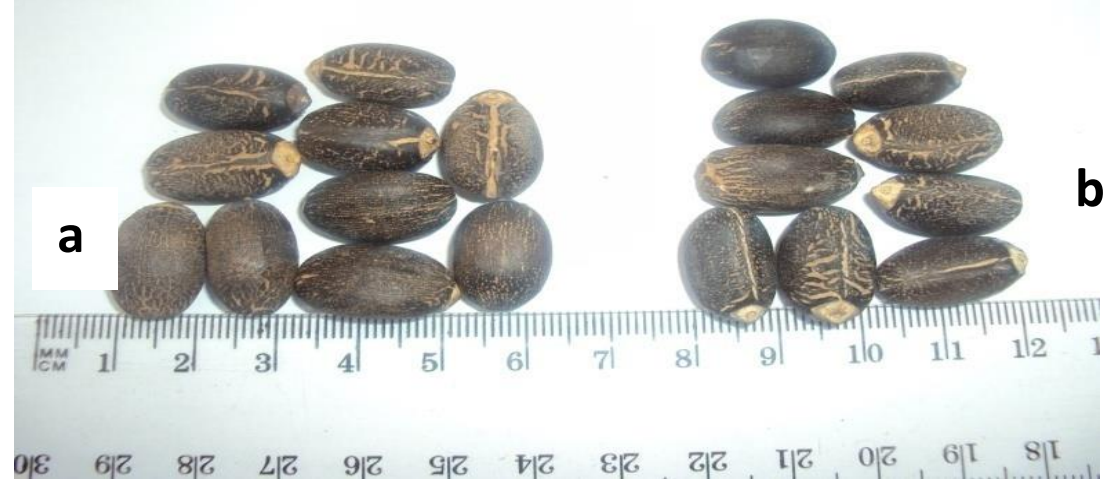

Figure 1: Jatropha curcas seeds from Cameroon (a) and from Chad (b).

The trial site was cleared and cleaned, tilled and demarcated into 10 by $6 \mathrm{~m}$ plots. Three beds separated with a space of $2 \mathrm{~m}$ each were made on each plot. 5 holes with $2 \mathrm{~m}$ spacing were dug in the middle of each bed.

The experimental design was a split plot with factor 1 being the origin of the seeds and factor 2 being 4 levels of fertilization (organic manure, mycorrhizae, chemical fertilizer and control) with three repetitions. J. curcas plants were placed $2 \mathrm{~m}$ apart in between lines and holes. Organic manure $(\mathrm{OM})$ consisted of dried cow dung $(2.5 \mathrm{~kg} / \mathrm{hole})$. Chemical fertilizer $(\mathrm{CF})$ applied was NPK (20-10-10) at a dose of 250g/hole). These two inputs were applied two weeks after seed germination. Mycorrhizae (M) inoculum obtained from the Biotechnology Centre in Yaoundé (Cameroon) was a mixture of Glomus clarum, Gigaspora margarita and Scutellespora sp. at a concentration of 20 spores/gram of substrate. $20 \mathrm{~g}$ of this substrate mixture was introduced into each hole during planting (Nwaga, 2009).

Seeds were pre-treated by soaking in cold water for 12 hours. Three healthy pre-treated seeds were put in each hole at a depth of $3-5 \mathrm{~cm}$. Thinning was done 14 days after germination to leave one plant per hole. Plots were maintained clean by hand weeding.

Data were collected on germination and survival of plants, growth parameters and fresh weight of plants as well as root mycorrhization (nodulation) from a sample of 30 plants. The mean leaf surface area was calculated using the formula by RAUNKIAER (Ngatchou, 1987) as:

Leaf Surface $=2 / 3\left(L^{*} 1\right)$

(Where $\mathrm{L}=$ length of limb, and $1=$ width of limb)

Dry matter (DM) was determined from plant samples dried under ambient temperature (air dried) for two days, followed by the oven at $105^{\circ} \mathrm{C}$ until constant dry weight was attained.

The rate of mycorrhizal colonization was evaluated as per Kormanick and Mc Graw (1992). 
The statistical package «Statgraphic plus 5.0» was used for analysis of variance (ANOVA) and for determining interactions between treatments. The Duncan test was used to compare the means.

\section{RESULTS AND DISCUSSION}

\subsection{Germination rate of seeds at two weeks after planting}

Seeds of J. curcas germinated between 6 to 14 days after sowing (DAS). Konaté (2006), Sharma (2007) and Nenwôla (2009) also observed that germination in J. curcas was averagely 10 days. There was a significant difference $(\mathrm{p}<0.05)$ in the impact of the different treatments on the germination rate of the seeds originating from Chad (Figure 2). The germination rate for the seeds originating from Chad were $49.0 \pm 7.2 \% ; 54.0 \pm 16.1 \%$ and $48.0 \pm 13.8 \%$ respectively, on plots that received organic manure, mycorrhizae and control. These values were $83.0 \pm 16.6$; $96 \pm 19.5$ and $82 \pm 13.5 \%$ respectively for the same treatments with the seeds originating from Cameroon. And for the latter, the difference is highly significant $(\mathrm{p}<0.001)$ between treatments. Seeds originating (accessions) from Cameroon, had a high germination rate as compared to those from Chad. Mycorrhizae stimulated the germination of seeds from both origins; $96.0 \pm 19.5 \%$ for Cameroon accessions and $54.0 \pm 16.1 \%$ for Chad accessions. This was likely due to water retention at the level of the radicles at the end of germination, a phenomenon commonly produced by fungi mycorrhizae. Earlier studies confirm the beneficial role of mycorrhizae in water and mineral supply/conduction in plants on dry land (Perret et al., 2000; Thuries et al., 2000).

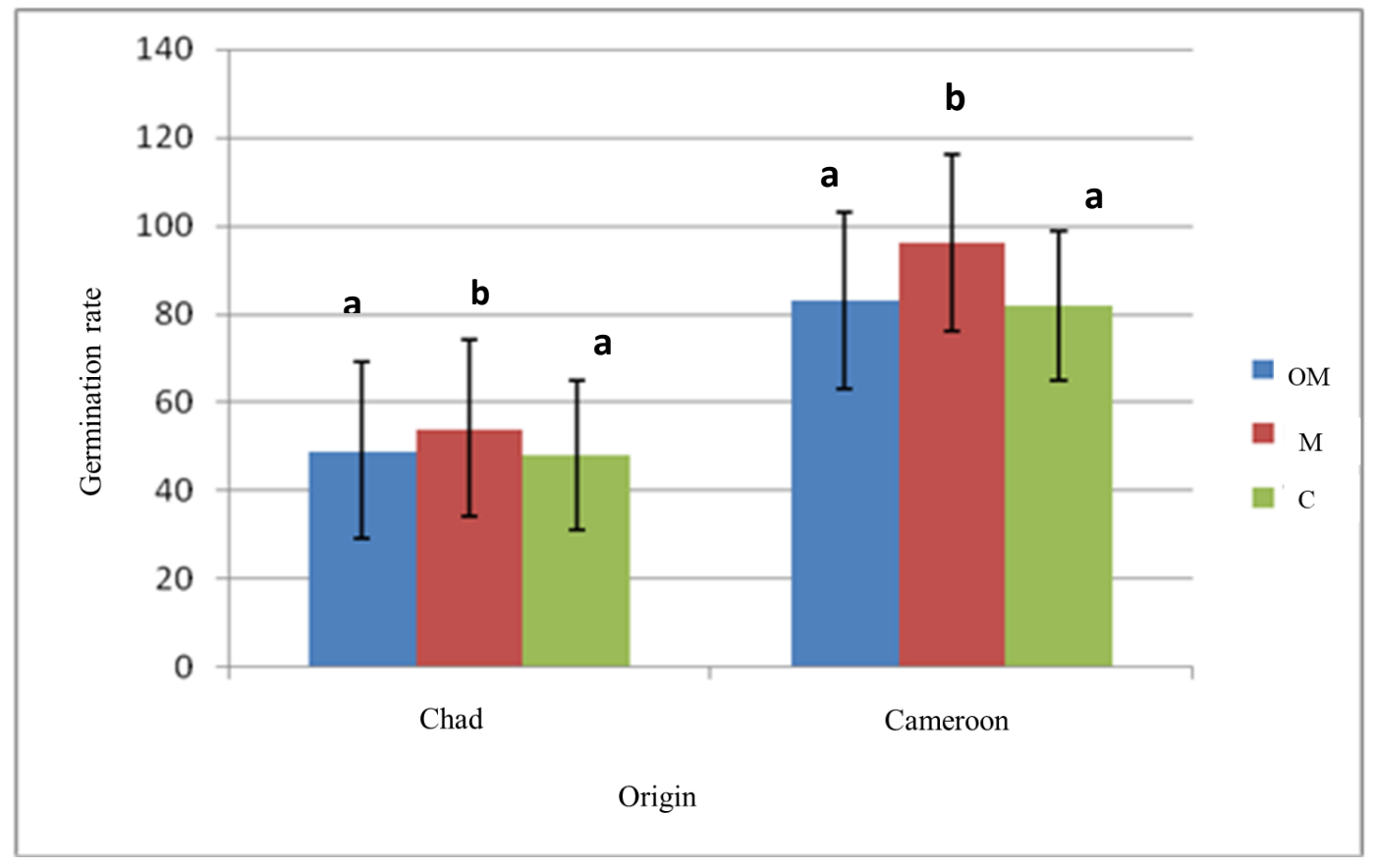

Figure 2: Germination rate of Jatropha curcas seeds at 14 DAS as per the different treatments OM: organic manure; M: Mycorrhizae; C: control; DAS: Day after sowing

Values on the bars from the same accession followed by the same letter is not significantly different $(\mathrm{p}<0.05)$ for Chad and $\mathrm{p}<0.001$ for Cameroon). 


\subsection{Effect of different treatments on the survival rate of the plants}

Compared to chemical fertilizers and control, mycorrhizae and organic manure significantly $(\mathrm{P}<$ 0.05 ) increased the survival rate of the plant at 180 DAS (Figure 3). The rates were 91.0 \pm 7.4; $95.0 \pm 3.2 ; 88.0 \pm 4.2 ; 88.0 \pm 2.5 \%$ respectively for the plots enriched with organic manure, mycorrhizae, chemical fertilizer and control for the Cameroon accessions. These values were $95.0 \pm 1.1 ; 91.0 \pm 1.1 ; 80.0 \pm 1.1$ and $86 \pm 2.5 \%$ for the Chad accessions. The high rate of survival observed on plots enriched with organic manure and mycorrhizae were probably due to the uptake of mineral salts by the plants and its positive impact during the dry season (November December). On the other hand, this result could be due to the capacity of environmental stress resistance conferred to the plant by the mycorrhizae (Bourou et al., 2011; Lounès-Hadj Sahraoui, 2013).

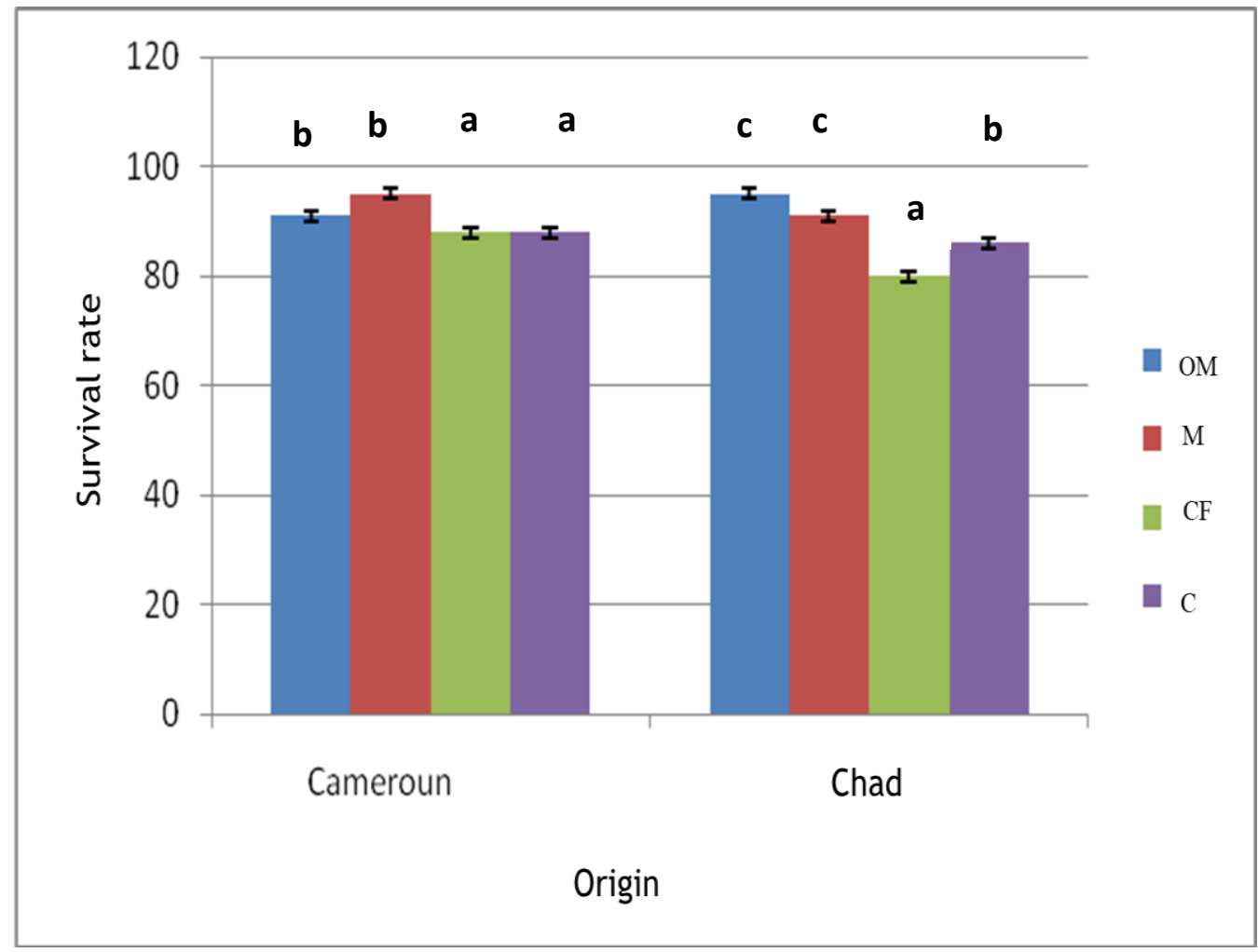

Figure 3: Suvival rate of Jatropha curcas plants at 180 DAS

OM: organic mqnure; M: Mycorrhizae; CF: Chemical fertilizer; C: control; DAS: Day after sowing

Values on the bars from the same accession followed by the same letter are not significantly different $(\mathrm{p}<0.05)$.

\subsection{Effect of different fertilizing agents on the growth of Jatropha curcas}

The difference was highly significant $(\mathrm{P}<0: 001)$ between the different treatments. Slow in the beginning, the growth rate (vertical) increased progressively with time (Figure 4). A gradual slow down was observed at 150 DAS for all two accessions. At 180 DAS, the height for 
Cameroon accession were $85.9 \pm 5.2,65.8 \pm 6.9,70.5 \pm 5.5$ and $57.6 \pm 7.3$ respectively for the treatments organic manure, mycorrhizae, chemical fertilizer and control. Corresponding values for plants from Chad were $63.9 \pm 1 \mathrm{~cm}, 39.9 \pm 4.7 \mathrm{~cm}, 50.4 \pm 4.3 \mathrm{~cm}$ and $37.8 \pm 4.5$. There was no significant difference between mycorrhizae treated plants and the control as of this date for the Chad accessions.

All the allocated treatments stimulated a vertical growth in all the $J$. curcas plants. Ouédraogo (2000) and Singh \& Rathod (2002) obtained similar results on the growth and development of $J$. curcas. These results are close to that of Tchobsala et al. (2008) who observed a positive influence of chemical fertilizers and organic manure on the vertical growth of $J$. curcas in the northern region of Cameroon, as well as that of Tchuenteu (2009) who noted a profitable effect of mycorrhizae and organic manure on the vegetative development of Ricinus communis at BiniDang (Ngaoundéré-Cameroon). When comparing the two accessions (Chad and Cameroon), these results show that the local accession (Cameroon) performed better in terms of vertical growth parameters.
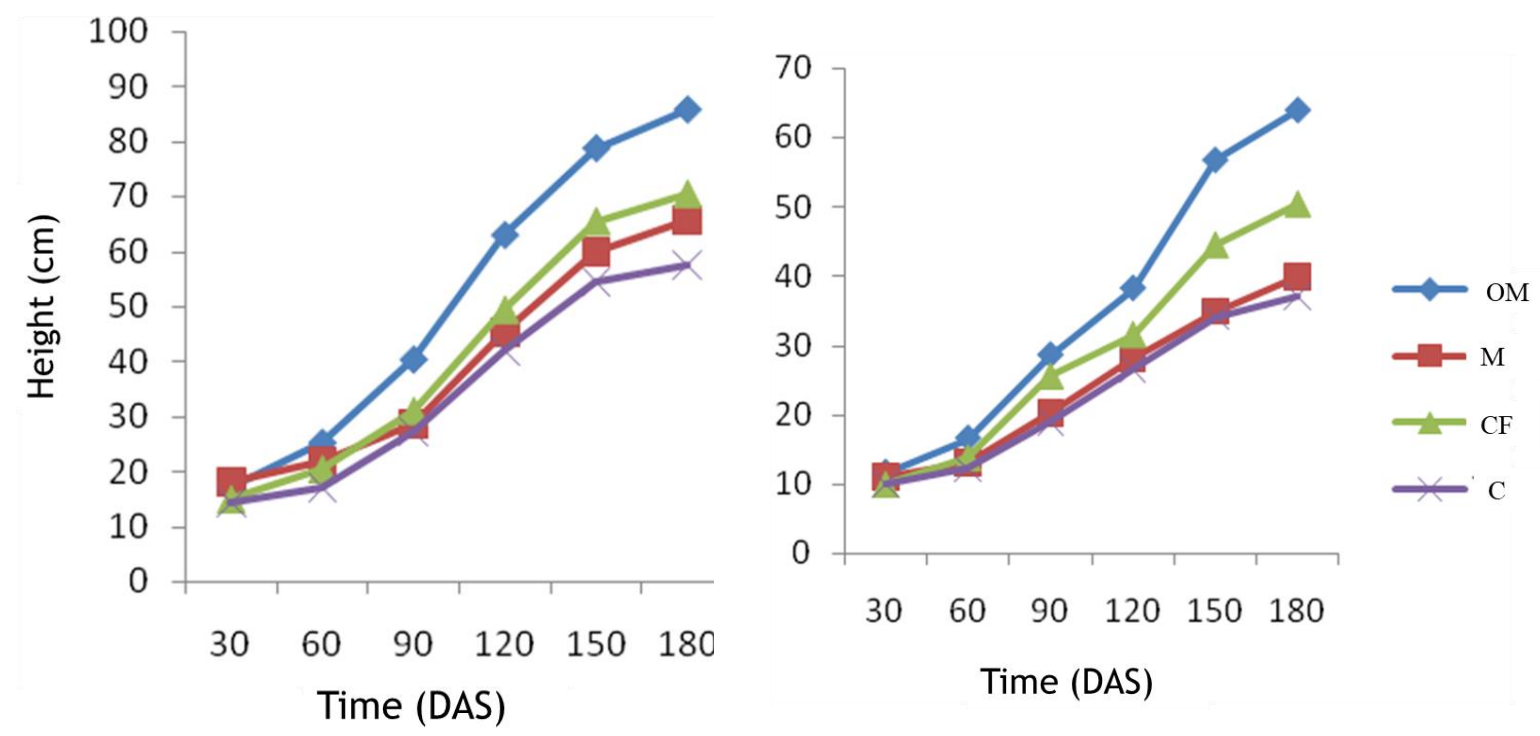

a. Origin Cameroon

b. Origin Chad

Figure 4: Impact of the different treatments on the variability of Jatropha curcas height at different points in time.

DAS : Day after sowing ; OM: organic manure; M: Mycorrhizae; CF: Chemical fertilizer; C: control.

\subsection{Effect of the different treatments on the number of leaves of $J$. curcas}

The different treatments had highly significant $(\mathrm{P}<0: 001)$ effects on the increase in leaf number at 180 DAS (Figure 5). The values were 65.0 $\pm 3.4,51.0 \pm 5.3,53.0 \pm 2.27$ and $46 \pm 3.76$ respectively for organic manure, mycorrhizae, chemical fertilizer and control. For the Chad

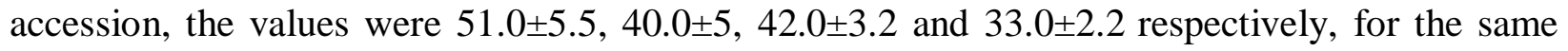
treatments at 180 DAS. 
Leaf formation was slow between 120 and 180 DAS. This period corresponds to the dry season months of November and December, when plants are stressed as a result of lack of water. The number of leaves on the control treatment from both accessions remained low throughout the trial period.

Increase in the number of leaves on the treated plots suggests that fertilization (organic and mycorrhizae) enhances photosynthetic activity which is necessary for effective physiological functioning of the plant. This leaf increase could have an important role in the fight against climate change in the Adamawa region of Cameroon, given their importance in Carbon sequestration through photosynthesis, thus limiting soil exposure to harmful solar radiation and consequently increasing soil relative humidity and reducing erosion (Wiesenhiitter, 2003). Bunch (2004) and Sall (2007) have shown that leaves represent recyclable biomass and organic matter which could produce mineral elements necessary for plant nutrition, with $J$. curcas having remarkable physiological potentials. Leye et al. (2009) reported that the inoculation of J. curcas with Glomus sp led to a significant increase in leaf number. Organic manure provides nutrients which help in increasing the organic matter, stabilizing the $\mathrm{pH}$, improving the structure and the water retention capacity of the soil; this explains the increase in the development of $J$. curcas as observed in all the plots amended with organic manure.

There was a highly significant correlation between plant height and leaf number in both accession $(\mathrm{R}=0.839 ; \mathrm{P}<0.001)$.

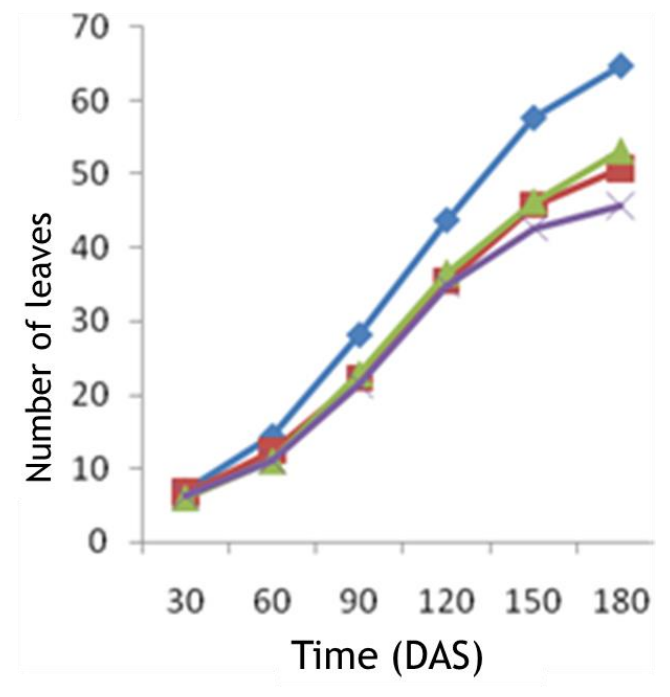

a. Provenance Cameroun

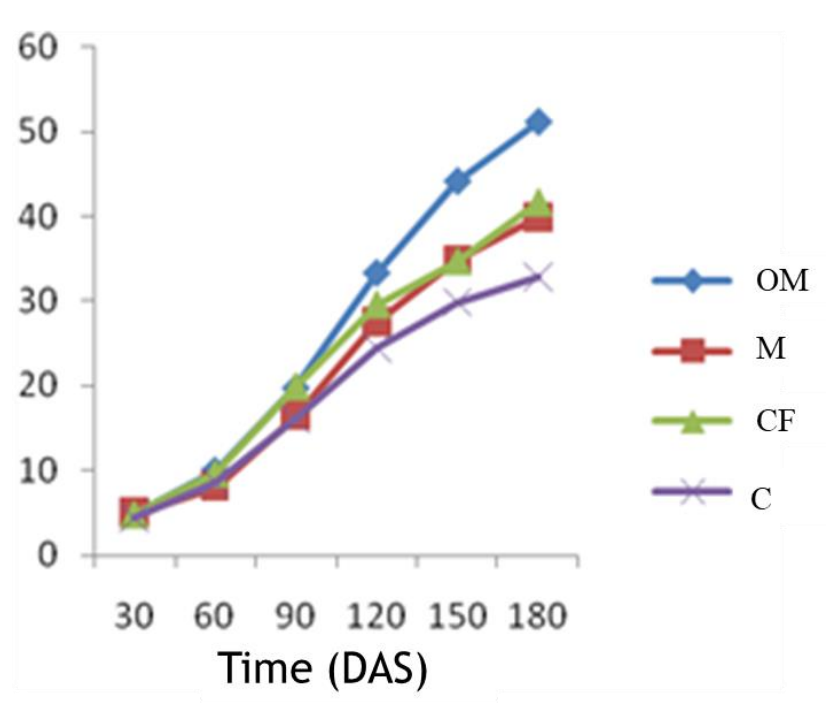

b. Provenance Tchad

Figure 5: Variations in the number of leaves at different points in time as affected by the different treatments.

DAS : Day after sowing ; OM: organic manure; M: Mycorrhizae; CF: Chemical fertilizer; C: control

3.5 Effects of the different treatments on the leaf surface area $\left(\mathrm{cm}^{2}\right)$ of Jathopha curcas Leaf surface area showed a significant $(\mathrm{P}<0.001)$ increase with the input of the various fertilizing agents and attained maximum from 90 to 120 DAP (Fig. 6). From 120 DAP, leaf surface area reduced greatly in both accessions. This reduction period corresponds to the dry season months 
of November and December when most plants loose considerable amounts of their leaves in order to withstand the dry season. This work is similar to that of Ouédraogo (2000), which showed that under stress conditions, J. curcas reduced surface leaf area or sheds leaves in order to withstand the drought.

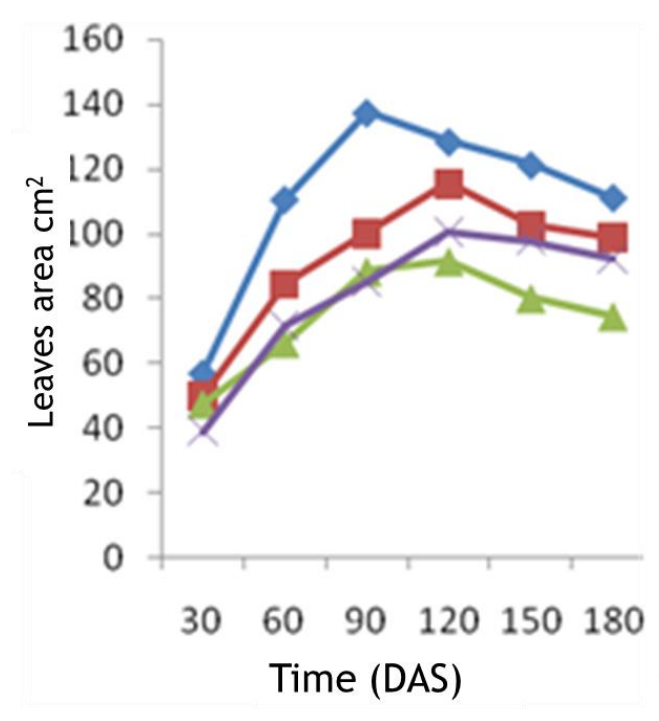

a. Origin Cameroon

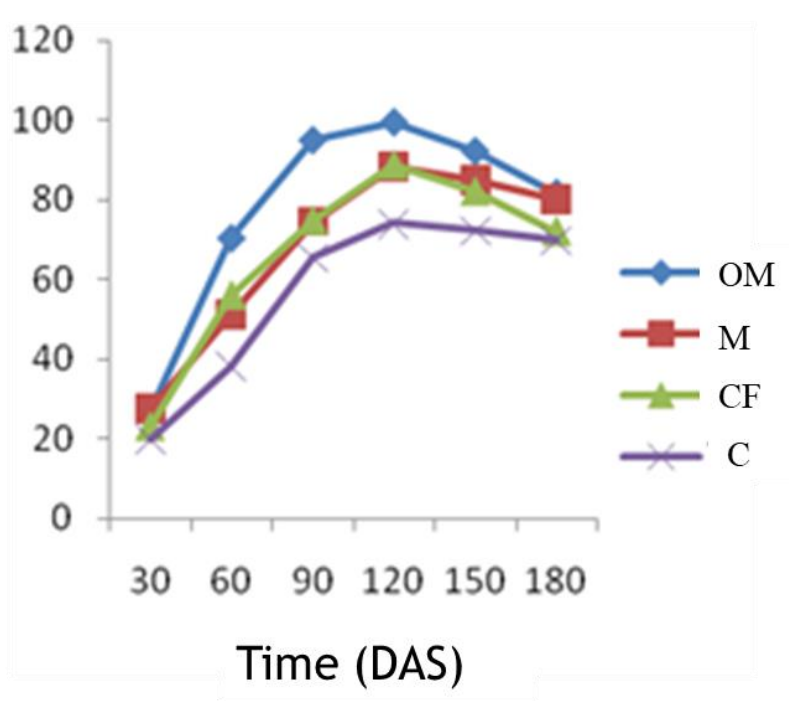

b. Origin Chad

Figure 6: Influence of the different treatments on the variation of leaf surface area of Jatropha curcas at different points in time.

DAS : Day after sowings; OM: organic manure; M: Mycorrhizae; CF: Chemical fertilizer; C: control

\subsection{Effect of the treatments on plant biomass yield}

The effect of organic manure, chemical fertilizer and mycorrhizae on the dry weight of Jatropha curcas plants is presented on figure 7. The different treatments significantly $(\mathrm{P}<0,001)$ influenced values of this parameter.

Total dry biomass produced by the Cameroon accession was highest in organic manure (239 \pm 9.6 g) followed by chemical fertilizer $(129.9 \pm 3.1 \mathrm{~g})$, then by mycorrhizae $(114.7 \pm 0.4 \mathrm{~g})$. The lowest dry biomass yield was obtained from control $(99.2 \pm 1.9 \mathrm{~g})$. These values from the Chad accession were $176.4 \pm 3.6,74.2 \pm 12.4,46.5 \pm 9.5$ and $43.2 \pm 2.8 \mathrm{~g}$ respectively for the same treatments. These results are in accordance with those of Tchuenteu (2009) who noted that organic manure increased biomass yields in Ricinus communis. Fertilization has a beneficial effect on dry biomass yields in $J$. curcas plants (Can et al., 2004; Janaludin et al., 2006).

There is a strong and positive correlation $(\mathrm{R}=0.854 ; \mathrm{P}<0.001$ for Chad accession and $\mathrm{R}=0.892 ; \mathrm{P}<0.001$ for Cameroon) between dry weight and height. 


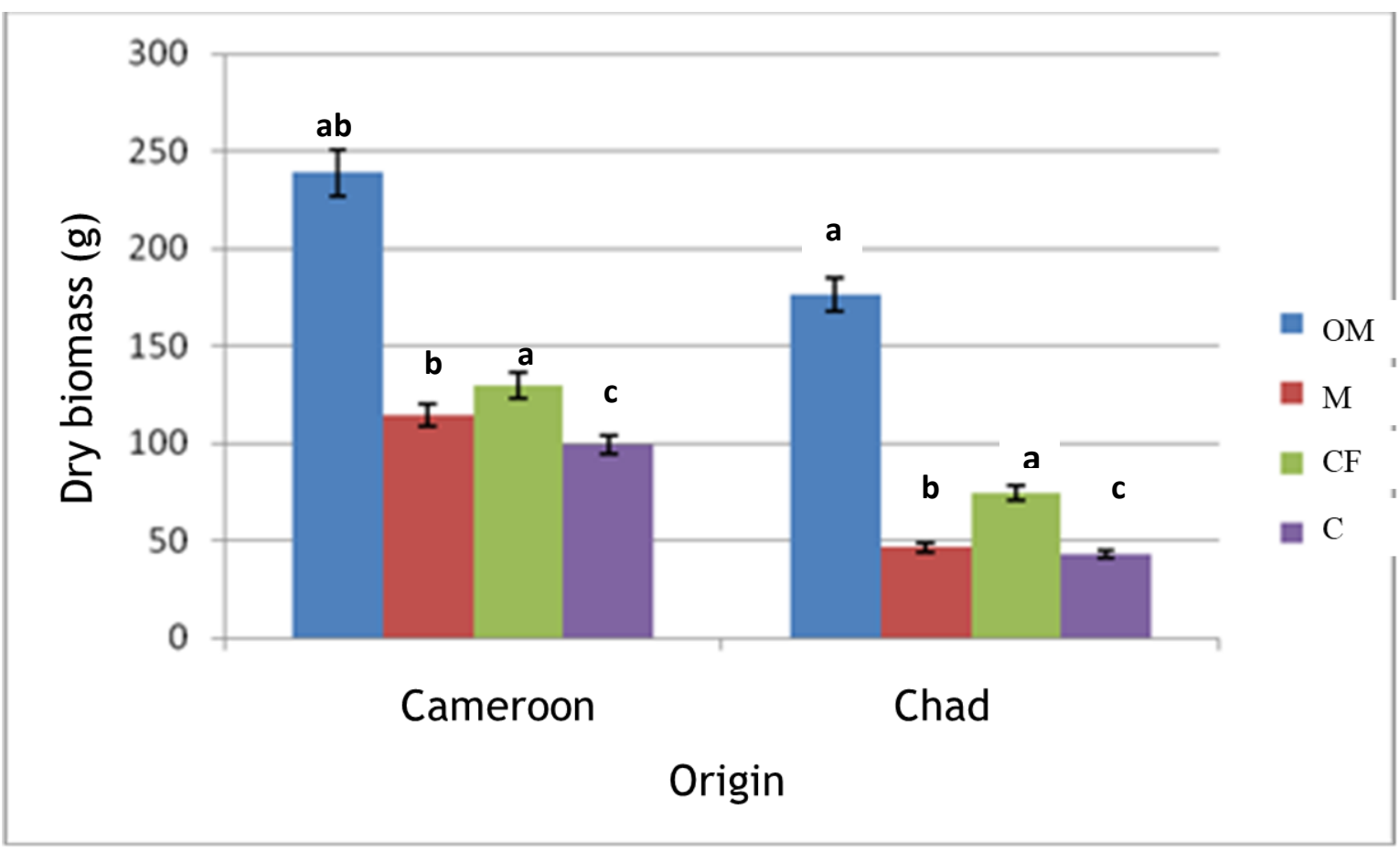

Figure 7 : Impact of treatments on dry biomass yields at 180 DAS

DAS: Day after sowings; OM: organic manure; M: Mycorrhizae; CF: Chemical fertilizer; C: control.

Values on the same set of bars followed by the same letters are not significantly different.

\subsection{Effect of treatments on water content of the plants}

Results obtained from the Cameroon accession shows high water content $(74.1 \pm 3.1 \%)$ of plants on Mycorrhizae treated plots compared to plants on organic manure $(70.7 \pm 7.3 \%)$, control $(71.7 \pm 4.3 \%)$ and chemical fertilizer $(68.5 \pm 5.3)$ treated plots. The effect of these treatments on the Chad accession was completely different from that of Cameroon accession (Figure 8). The high water content in plants of the Cameroon accession could be due to a more favorable response to environmental conditions. Mycorrhizae contribute more in water uptake and resistance to drought, which justifies the higher water content in plants in the mycorrhizae inoculated plots (Perrin, 1991; Megueni et al., 2011).

According to Ouédraogo (2000), J. curcas retains three major adaptive characteristics which enhance its resistance to drought: a strong root development, a cuticle protection of aboveground structures and a reduction or shedding of leaves, which highly limits loses through transpiration. Actually, leaf loss (defoliation) was more pronounced on the organic manure treated plots $(61 \%)$ and on the mycorrhizae treated plots $(32 \%)$ for the Cameroon accession.

Improvement with organic manure and mycorrhizae conferred to the plant potentials for resistance to environmental stress. 


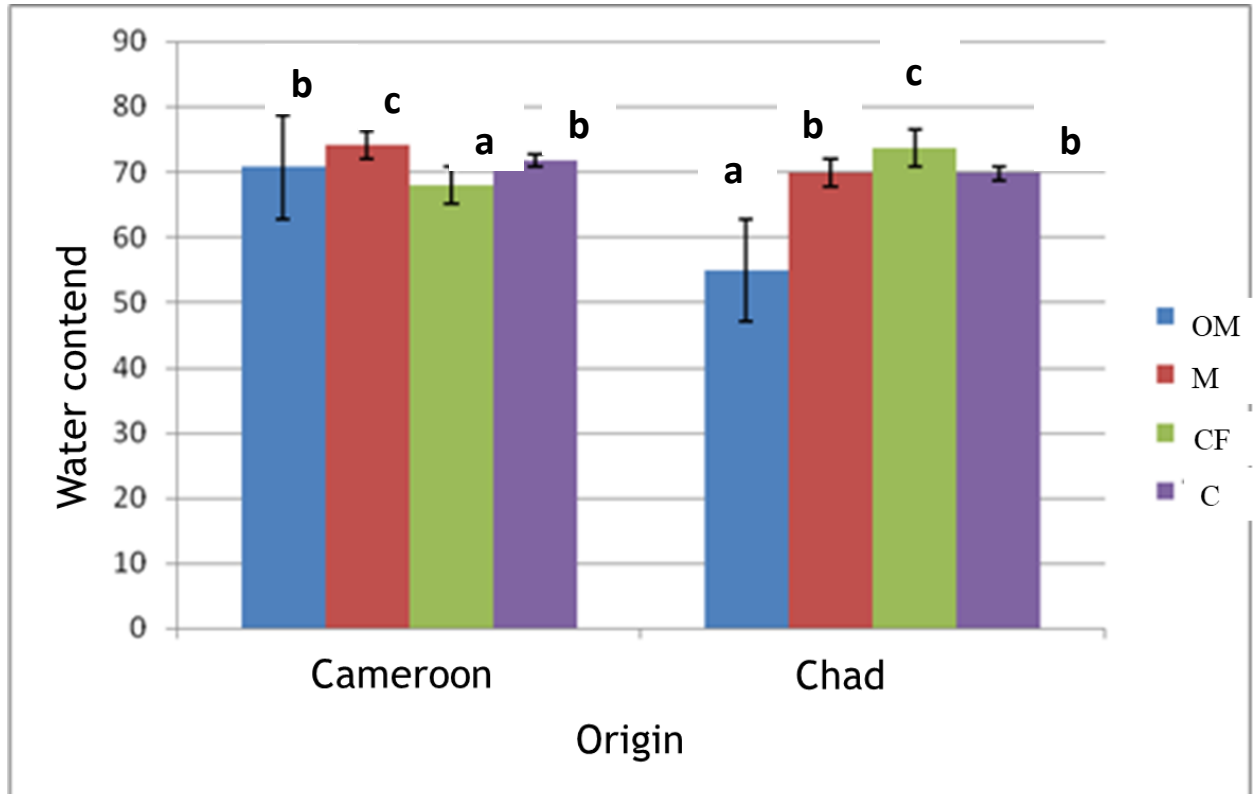

Figure 8: Effect of treatments on water content of Jatropha curcas plants at 180 DAS C: control

DAS: Day after sowing; OM: organic manure; M: Mycorrhizae; CF: Chemical fertilizer; Values on the same set of bars followed by the same letters are not significantly different

\subsection{Effect of different treatments on the mycorrhization rate of the $\boldsymbol{J}$. curcas roots}

Root colonization by mycorrhizae showed a highly significant difference $(\mathrm{P}<0,001)$ between the seeds from the two origins (Table 4). The roots mycorrhization rate was lowest on chemical fertilizer treated plots compared to the other treatments. This shows that chemical fertilizer pollutes the environment and disturbs the development of soil microflora (Nwaga, 2000 ; Tremier et al., 2002 ; Lachance and Rouleau, 2004). The sustainable management of soils for crop production would require the use of organic and biological fertilizers (Estève, 1996; Fresco, 2003 and Megueni et al., 2011).

Tableau 4: Effect of the different treatments on the mycorrhization rate of Jatropha curcas root at $180 \mathrm{DAS}$

\begin{tabular}{|llllll|}
\hline Origin & OM & M & CF & C & P \\
\hline Cameroon & $28.80 \pm 0.40^{\mathrm{c}}$ & $40.49 \pm 0.23^{\mathrm{d}}$ & $10.13 \pm 0.21^{\mathrm{a}}$ & $20.57 \pm 25^{\mathrm{b}}$ & 0.001 \\
Chad & $26.31 \pm 1.5^{\mathrm{c}}$ & $40.23 \pm 1.11^{\mathrm{d}}$ & $13.28 \pm 1.14^{\mathrm{a}}$ & $20.15 \pm 2,55^{\mathrm{b}}$ & 0.001 \\
\hline
\end{tabular}

OM: organic manure; M: Mycorrhizae; CF: chemical fertilizer; C: Control. DAS: Day after sowing Line means with the same superscripts are not significantly different $(\mathrm{p}<0.001)$ 
Vol. 5, No. 06; 2020

ISSN: $2456-8643$

\section{CONCLUSION AND PERSPECTIVES}

At the end of this study, it is worth retaining that fertilizers significantly improved the growth, yield and the rate of root mycorrhizal colonization in the two accessions (Cameroon and Chad) of Jatropha curcas.

Germination in the two accessions was attained at two weeks after planting. The germination rate was higher for the Cameroon accession. Mycorrhizae improve the seeds germination rate and survival of the plants of the two accessions, as well as the water content. Mycorrhizae confer on J. curcas plants drought resistance properties such as defoliation and increase in water content. The Cameroon accession was better adapted to the study site than the accession from Chad. As concerns yields, plant dry weight was highest in the organic manure treated plants, followed by the chemical fertilizer, mycorrhizae and control in both accessions (Cameroon and Chad). The mycorrhization rate was lower on roots of plants in chemical fertilizer treated plots than in the control, which affirms the destruction of soil microflora by chemical fertilizers.

Good development of $J$. curcas requires input of organic material or mycorrhizae. In terms of agronomy, the local accession of $J$. curcas can be integrated in the vulgarization/extension program in the Guinea-savannah region of the Adamawa (Cameroon).

\section{REFERENCES}

Antonios P., 2002. Le développement agricole durable : rêve ou réalité. Le courrier ACP-UE, 193:28-29

Bellefontaine R., Petit S., pain O. M., Deleporte P. \& Bertault J. G., 2001. Les arbres hors forêt vers une meilleure prise en compte. F.A.O, Conservation. Rome. 231p.

Bourou S., Ndiaye F., Diouf M. \& Van Danme P., 2011 : Effets de l'inoculation mycorhizienne sur le comportement agro-physiologique des écotypes du tamarinier (Tamarindus indica L.) au Sénégal. J. Appl. Biosci.46 : 3093-3102

Bunch R., 2004. Engrais verts et culture de couverture. Agridape, 19 (1): 16-148.

Chisti Y., 2007. Biodiesel from microalgae. Biotechnology advances, 25: 294-306.

Dauriat A., Fromentin A. \& Sarlos G., 2001. Rapport sur les possibilités d'utilisation des

Biocarburants à l'Aéroport International de Genève, Ecole polytechnique fédérale de Lausanne, Genève. 129p.

Dieye P.N., 2007. Les biocarburants : une nouvelle donne pour les politiques agricoles. Agrovision, 4 : 14-15.

Estève B., N'Dayegamiye A. \& Coderre D., 1996 The effect on earthworm abundance and selected soil properties After 14 years of cattle manure and slid NPKMg fertilizer application. Study and Soil Management 7 (1) : 73-88.

Fall A., 2007. De nouvelles pistes vers la souveraineté énergétique. Agrovision, (4) : 10-13.

Fresco O. L., 2003 Fertilizers and future. In: Global Security and the Role of fertilization long lasting. Maisonneuve Larousse (eds). Conference IFA / FAO. Rome. Italie.26-28 March 2003

Hammaoui H., 2006. L'effet nématocides de quelles que plantes sur les nématodes à galles de la culture de tomate, Mémoire de Master, Université d'Agadir, Maroc. 61p.

Jacquet P., Rajeudra K. \& Tubiana L., 2009. Regard sur la terre 2009, l'annuel du 
développement durable-la gouvernance du développement durable, Presses de Sciences. Pp. 12-14

Konaté M., 2006. Introduction d'une technique culturale du pourghère (Jatropha curcas L.) dans la commune de Garalo, IPR/IFRA de Katibougou, mémoire de fin de cycle, décembre 2006. 56p.

Lachance P. \& Rouleau D., 2004. Culture sans herbicide : les facteurs de réussite. Ed. Lavoisier. Paris. $125 \mathrm{p}$.

Leye E. H. M., Ndiaye M., Ndiaye F., Diallo B., Sarr A. S., Diouf M. \& Diop, 2009. Effet de la mycorhization sur la croissance et le développement de Jatropha curcas. Revue des Energies Renouvelables 12 (2) : 269-278.

Lounès-Hadj Sahraoui A., 2013. La Mycorhize à arbuscules : quels bénéfices pour l'homme et son environnement dans un contexte de développement durable? Rev. Sci. Technol., Synthèse : 26 : 06-19.

Megueni C., Awono T. \& Ndjouenkeu R., 2011 : Effet simultané de la dilution et de la combinaison du Rhizobium et des mycorhizes sur la production foliaire et les propriétés physico-chimiques des jeunes feuilles de Vigna unguiculata (L.) Walp. J. Appl. Biosci. 40 : 2668-2676.

Nenwôla K.B, 2009. Caractérisation agronomique de Jatropha curcas (L.) dans la zone cotonnière du nord Cameroun et quantification des huiles issues de leurs graines. Mémoire de Master en Biologie des Organismes Végétaux, Université de Ngaoundéré. 52p.

Ngatchou N. J., 1987. Enjeu de la conservation des ressources génétiques. IRA Yaoundé. In : Biosciences, $1990 ; 241$ - 393.

Nwaga D., 2000. Agriculture biologique et alternative de la biofertilisation. In : l'utilisation des biofertilisants microbiens pour la culture durable. In: Actes du premier atelier de formation organisé par l'UMAB. Université de Yaoundé I, du 31 mars au $1^{\text {er }}$ avril 2000, 23- 24.

Nwaga D., 2009. Biocarburants, sols marginaux et sécurité alimentaire, 25p. In : Biosciences and Food Security. $16^{\text {ème }}$ Conférence du Comité Camerounais des Biosciences. $105 \mathrm{p}$.

Olivier D, 2007. Jatropha curcas: une plante à très fort potentiel. In : planète bleue. Poésie en image et Ecologie en action. Actualité de l'environnement. $7 \mathrm{p}$.

Ouédraogo M., 2000. Etude biologique et physiologie du Phourgère, Jatropha curcas L. thèse d'Etat. Université de Ouagadougou, Burkina-Faso. 290p.

Péan V., Allaire G. \& Bancel D., 2005. Rapport sur la restitution de la conversation de la maison Midi-Pyrénées. Biocarburants: des controverses à toutes pompes, comment poser des arguments du débat ? Éd. Mission Agro biosciences, Pierre Verdier, Midi-Pyrénées : 18p

Perret X. C., Stachelin \& Broughton W. J., 2000. Molecular basis of symbiotic promiscuity. Microbial. Rev. 59 : 124-142.

Perrin, 1991. Les mycorhizes et protection phytosanitaire $I n$ : Les mycorhizes des arbres et des plantes cultivées. Technique et développement. Lavoisier. Paris. 250p.

Sall H.M., 2007. Rapport annuel de projet biocarburant 2007-2012 : nouvelle orientation de la politique agricole au Sénégal, Ministre de Développement rural et de l'agriculture : $24 \mathrm{p}$.

Singh G. \& Rathod T. R.; 2002. Plants growth biomass production and water dynamic in a shifting dume of Indian desert. Forest Ecology and management, 173 (3): 309-320.

Sharma N., 2007. Effect of germination on raised bed and nursery in different provenance of 
Jatropha curcas L. expert seminar on Jatropha curcas. Agronomy and genetic, 26-28 March 2007. Washington. The Netherlands. Published by FACT Fondation.

Tchobsala, Amougou A., Abou A.A., Nadama \& Wey J., 2008. Inventaire des variétés de Jatropha curcas dans la zone cotonnière du Nord Cameroun. Rapport de la mission du 13 au 26 mars 2008. 34p.

Tchuenteu T. L., 2009. Effets des mycorhizes et de la fumure organique sur la croissance et le développement du ricin (Ricinus communis L.) cultivé en champs dans la région de BiniDang (Ngaoundéré-Cameroun). Mémoire de Master en Biologie des Organismes Végétale, Université de Ngaoundéré. 50p.

Thuries L., Arrufat A., Dubois M., Felerc, Hermann P., Larré I. E., Martin C., Pansu M., Remy J. C. \& Viel M., 2000. Influence d'une fertilisation organique et de la solarisation sur la productivité maraîchère et les propriétés d'un sol sableux sous-abri. Etude et gestion des sols. 7(1) : 73-88.

Tremier A., De Guardia A. \& Massini C., 2002. A respirometric method to study biodegradation kinetics of mixed sludge and woody bulking agent. In ramira 2002-FAO: $10^{\text {th }}$ international conference on management strategies for organic waste used in agriculture, Pleso, Slovaquia, May 14-2002. 5p.

Wiesenhütter J., 2003. Use of the physic nut (Jatropha curcas) to combat desertification and reduce poverty. Sci. Tech. J. 7: 55-60. 